DOI: https://doi.org/10.31392/NZ-npu-143.2019.23

УДК 37:929(093.3)

ORCID ID 0000-0002-6146-9844

Трифонова О. М.

\title{
МЕТОДОЛОГІЧНІ АСПЕКТИ РОЗВ'ЯЗАННЯ СУПЕРЕЧНОСТЕЙ В ХОДІ РОЗВИТКУ ІНФОРМАЦІЙНО-ЦИФРОВОЇ КОМПЕТЕНТНОСТІ МАЙБУТНІХ ФАХІВЦІВ КОМП'ЮТЕРНИХ ТЕХНОЛОГІЙ
}

У статті розглядаються методологічні аспекти вирішення суперечностей в ході розвитку інформаційно-цифрової компетентності майбутніх фахівиів компютерних технологій при навчанні фізики та технічних дисииплін в педагогічному закладі вищої освіти на основі Конщепиії розвитку цифрової економіки та суспільства Украйни на 2018-2020 роки. Ця кониепиія, а також парадигма реформування освіти в Украӥні передбачають створення сучасного освітнього середовища, де має бути подолана система суперечностей між нескінченністю розвитку предмету пізнання природи й обмеженістю можливості інформаційно-иифрової компетентності (ІЦК) суб'єкта ї̈ пізнання. Розглядаються умови створення сучасного освітнього середовища, де має бути подолана система суперечностей між нескінченністю розвитку предмету пізнання природи й обмеженістю можливості інформаційно-цифрової компетентності суб'єкта ї̈ пізнання. Окреслено методологічні передумови для забезпечення глобальних змін цифровізації освіти в напрямку ї̈ компетентнісної модернізації, визначено конкретні завдання трансформації освіти в циифровий простір. Основу методології складає процес розвитку мислення та формування світогляду суб'єктів навчання в єдиному чуттєво практичному операційному середовищі самодисиипліни, компетентної роботи з інформацією, моделями, алгоритмами.

Також у статті розглянуто аспекти прояву суперечності між нескінченістю предмету пізнання (безумовність) і скінченістю (умовність) умов пізнання, які вирішуються в процесі поступального розвитку пізнання в напрямку до істини. Вирішення суперечностей згідно ланщюжка складає кінщевий підсумок кожного етапу окремого руху пізнання до розкриття чергової істини як елементу абсолютної істини, до чого намагається дійти особистісне пізнання. Вирішення визначених суперечностей і складає предмет дослідження, окресленого статтею.

Ключові слова: цифрровий простір, компютерні технологї, компетентність, методологія, суперечності.

Концепція сталого розвитку [12], Концепція розвитку цифрової економіки та суспільства України на 2018-2020 роки [5], Концепція розвитку педагогічної освіти [4], Національна стратегія розвитку освіти в Україні на 2012-2021 роки [11], парадигма реформування освіти в Україні [10] передбачають створення сучасного освітнього середовища, де має бути подолана система суперечностей між нескінченністю розвитку предмету пізнання природи й обмеженістю можливості інформаційно-цифрової компетентності (ІЦК) суб'єкта ії пізнання. Вказані нормативні документи створюють певні методологічні передумови для забезпечення глобальних змін освіти в напрямку її компетентнісної модернізації, проте не визначають конкретних завдань докорінної трансформації освіти 3 реалізації накресленого. На практиці має місце переважно наповнення оновлених 
змістом старих традиційних освітніх форм. У цьому плані підтвердженням однієї з суперечностей $€$ низькі темпи упровадження електронних засобів навчання. Зокрема, в бюджеті МОН на 2018 р. було передбачено 732 млн грн на паперові підручники, тоді як на електронні - 40,9 млн грн [9]. За даними Інституту освітньої аналітики з 16 тис. українських закладів середньої освіти в країні 5600 (34\%) забезпечені 20-ма і більше комп'ютерами, а належним програмним забезпеченням і того менше. Виникає проблема санітарних норм і правил у частині обмеженості у часі праці суб'єктів навчання за комп'ютерами, потребує приведення до норм площ навчальних приміщень та ін. [7]. Не враховується, що компетентнісна модернізація освіти передбачає упровадження нової фрілософрії освіти, а не лише удосконалення форм та методів навчання.

Підготовка конкурентоспроможних висококваліфікованих фрахівців, здатних оволодіти інформаційно-цифровими (ІЦ) технологіями, передбачає, насамперед, окреслення методології формування належної їхньої компетентності, яка включає: сукупність наукових прийомів дослідження; вчення про методи пізнання та перетворення дійсності; критичний аналіз інформаційно-комунікаційних технологій зі створення, пошуку, обробки, обміну інформацією у навчанні, публічному просторі, приватному спілкуванні; інформаційну й медіа-грамотність; етики роботи з інформацією та ін. Основу методології складає процес розвитку мислення та формування світогляду суб'єктів навчання в єдиному чуттєво практичному операційному середовищі самодисципліни, компетентної роботи з інформацією, моделями, алгоритмами. Значна частина вчених виокремлюють фрілософську або фундаментальну її частину як систему діалектичних методів, які $\epsilon$ найзагальнішими і діють на всьому полі наукового пізнання, конкретизуючись через загальнонаукову і конкретну методологію та загальнонаукові підходи і методи дослідження [8].

Методологічний підхід не є новим поняттям. Сутність його полягає у тому, що він проявляється по-різному у різних умовах суспільного розвитку. Підвалини методології заклали ще Сократ, Платон, Арістотель, І. Кант, Г. Гегель, Р. Декарт, К. Маркс та ін.

У 90-х роках минулого століття концептуально методологічну основу компетентнісно орієнтованої освіти інформаційного суспільства заклали Н. Ашбашкіна, Г.Балл, С.У. Гончаренко, Р. Гуревич, І. Зязюн, В. Г. Кремень, Н. Г. Ничкало, О.Я. Савченко. Але на той час ще не складалося методологічного усвідомлення необхідності ґрунтовної перебудови освіти на компетентнісній основі. Тоді увага науковців концентрувалася на формування компетентності у конкретних галузях знань. Закономірно О. В. Овчарук має рацію, коли стверджує, що освіта в Україні 3 запізненням порівняно із західними державами почала оперувати поняттями компетентності у нових освітніх стандартах [6]. Немає системного і узгодженого підходу, насамперед до вироблення узагальнених методологічних підходів до формування професійної компетентності у практичній сфрері. Особливість нинішнього часу полягає у тому, що окрім професійної компетентності у майбутніх фахівців, що володіють комп'ютерними технологіями, необхідно фрормувати ще й таку важливу компоненту, як психолого-педагогічну готовність до виконання фрахових дій. 
Meта статmi полягає у дослідженні методології розвитку інфоормаційноцифрової компетентності, закономірностей виникнення та вирішення суперечностей, які створюються між об'єктом та суб'єктом освітнього процесу в ході розвитку ІЦК у майбутніх фахівців комп'ютерних технологій.

Теоретичний аналіз досліджень мислителів та науковців із проблем методології вирішення суперечностей між об'єктом та суб'єктом освітнього процесу.

На нашу думку, визначені вище проблеми доцільно вирішувати з розгляду основних понять методології, до яких належать об'єкти та суб'єкти, природа і пізнання, особистість і розвиток, пізнання і взаємозв'язок, процес і суперечність. Серед цих понять особливе місце займає поняття суперечність, як джерело, внутрішній імпульс усіх процесів розвитку, зокрема і в освіті та теорії навчання [2].

Особливе місце у виявленні та вирішенні суперечностей як джерела руху, розвитку належить науці фізиці та техніко-технологічним й ІЦ галузям науки i техніки, а відповідно й навчальним дисциплінам у закладах вищої освіти цього спрямування. Виходячи з фракту, що процес фрормування науково-педагогічних висококваліфікованих фрахівців $є$ багатогранним і багатоаспектним, усвідомлення суб'єктами навчання суперечностей, що виникають між об'єктом і суб'єктом, наукою і технікою, природою і пізнанням оволодіння внутрішніми рушійними силами пізнання $\epsilon$ особливо актуальним завданням. Рушійними силами досягнення результату в ході пізнання насамперед виступають психологічні відчуття студентами труднощів, що виникають в процесі пізнання об'єкта та виконання завдань з практичного перетворення ІЦ технологій у безпосередню виробничу силу. Вони виступають генератором активізації розумової діяльності особистості, спонукають до мотивованих пізнавальних дій і лежать в основі методів формування компетентного фрахівця, здатного вирішувати суперечності, чим забезпечуються належні умови інтелектуального розвитку суб'єктів пізнання. Рушійні сили мають латентний характер, малопомітні, виступають результатом суперечностей між пізнавальними завданнями, з одного боку, та наявним рівнем компетентності - з другого. Тут взаємодіють професійна ІЦК та готовність суб’єкту навчання до практичних дій.

Тому невипадково дослідження суперечності між об'єктом (природознавством), що вивчається, і суб'єктом пізнання завжди було предметом дискусій мислителів, учених всіх пройдешніх і нинішнього поколінь.

У процесі розвитку закономірностей пізнання природознавства в історії науки найбільш загальною суперечністю виступає суперечність між нескінченністю i необмеженістю предмету пізнання, цілісним проявом природи і скінченістю й обмеженістю пізнаної суб'єктами навчання ії частини. Природознавство та її складові (фізика, технічні дисципліни та ін.) нескінчені і невичерпні в їх властивостях й характеристиках явищ та процесів, зв'язках та відношеннях, розвитку і мінливості. Через історичну обумовленість і стадії розвитку суб'єкти навчання здатні у певних рамках пізнати природничі дисципліни і природу в цілому, як і окремі їі складові. У силу такої обумовленості визначаються рамки i межі відносності, які постійно знімаються і нівелюються в процесі пізнання. Проте у кожен момент все одно досягається умовний рівень відносного рівня знань предмету ІЦК, який ніколи не $є$ абсолютно повним і до кінця пізнаним у його 
властивостях, перетвореннях та зв'язках.

3 погляду викладеного ми розглянули аспекти прояву суперечності між нескінченістю предмету пізнання (безумовність) і скінченістю (умовність) умов пізнання, які вирішуються в процесі поступального розвитку пізнання в напрямку до істини. В точках біфуркації такі суперечності у пізнанні вирішуються і “прориваються", коли досягається попередня межа проникнення пізнання у предмет дослідження. Порушення попереднього історичного етапу меж пізнання студентом ІЦ технологій та наукою їх розвитку обумовлюються тим, що за тенденціями свого розвитку, можливостями і здібностями вони такі ж нескінчені і необмежені, як і сам предмет дослідження. Проте після “прориву” попередніх меж пізнання, наприклад, класичної фрізики, буде досягатися нова, більш вища межа знань предмету, - квантова фрізика, більш вищий рівень пізнання властивостей, зв'язків, перетворень, і тут же виникає нова суперечність, що виникає на новому, більш високому щаблі розвитку предмету дослідження - квантова теорія поля.

Таким чином, має місце постійне перманентне створення та вирішення нескінченого ланцюжка суперечностей, що складає процес розвитку пізнання. 3 фрілософрського погляду, постійне послідовне створення й вирішення суперечностей у процесі пізнання відображається у співвідношенні об'єктивної, абсолютної та відносної істини. Об'єктивним є предмет пізнання. Його знання відображає об'єктивний зміст людського пізнання, є неповним і невичерпним та відносним щодо досягнутості ступеня знання предмету. Згідно законів самоорганізуючих систем, рух пізнання здійснюється за ланцюжком: створена суспільством істина ® флуктуації (внаслідок взаємодії 3 навколишнім середовищем) ® наростання суперечності ${ }^{\circledR}$ біфуркація $®$ більш повна і глибока істина $®$ нові фллукуації $®$ наростання нових суперечностей $®$ біфуркація $®$ наступна більш глобальна істина ${ }^{\circledR} . . . .{ }^{\circledR}$ постійне виникнення зняття, і нове створення суперечностей. Постійно створюючи нові суперечності проявляються між необмеженим і нескінченим за своєю природою об'єктом пізнання і обмеженим кінцевим за своїм змістом пізнання цього об'єкта суб'єктом пізнання [13]. За таким ланцюжком здійснювався розвиток кібернетика інформатика - ІКТ - ІЦ технології. На нашу думку, нині виникли суперечності між вимогами суспільства до широкого використання ІЦ технологій і матеріальною базою його забезпечення; наявною інформаційно-цифровою технологією і готовністю суб'єктів навчання оволодіти нею; освітянськими можливостями розвивати інформаційно-цифрову компетентність в ході навчання студентів і включенням в цей процес комерційних структур держави. Вирішення визначених суперечностей і складає предмет дослідження, окресленого статтею.

Згідно із законами діалектики [3], такий ланцюжок означає, що сума відносних істин буде складати абсолютну істину, до якої входять основні ідеї, положення, висновки відносних істин. Наслідком вирішення суперечностей $\epsilon$ розвиток ІЦК у ході пізнання особистістю природничих дисциплін майбутніх фахівців комп'ютерних технологій. Зняття, вирішення суперечностей здійснюється своєрідно і неоднозначно, бо відображення предмету не збігається з самим предметом як за змістом, так і за утворенням.

Суб'єкти навчання (пізнання) у своїй свідомості відображають існуючий незалежно від них предмет пізнання. Але свідомість не $€$ дзеркальним 
відображенням предмету пізнання. В ході пізнання самим суб'єктом для накопичення абсолютної, об'єктивної істини вносяться елементи, які не властиві цьому предмету, й які в ході тривалої перевірки відсіваються, якщо не відображають властивості досліджуваного предмету. В історії розвитку науки і техніки так було, коли виникала теорія фрлогістону (за його заперечення Антуана де Лавуазье у 1783 р. був підданий символічному спаленню, як єретик науки), потім теплороду (М.В.Ломоносов), пізніше молекулярно-кінетична теорія (Дж. Максвелла), теорія електромагнітних хвиль, ефір, сучасна теорія поля і речовини та ін. Тут має місце визначений раніше ланцюг створення та вирішення суперечностей. Аналіз приведеного ланцюжка розкриття відносних істин показує , що така зміна не означає в загальному випадку послідовності виникнення відповідних їм ступенів у розвитку самого об'єкта пізнання, бо природа і структура предмету вивчення $€$ об'єктивною; а пізнавальний процес $€$ внутрішньо специфічним. I тоді, коли вноситься щось стороннє, невластиве наявному предмету дослідження, через специфіку процесу відображення, що не відтворює предмет пізнання, виникає суперечність, обумовлена більш загальною суперечливістю між об'єктом дослідження і суб'єктом пізнання, а відповідно між предметом пізнання і процесом пізнання. Ця суперечність вирішується за результатами реалізації накопичень пізнання, коли з'ясовується невідповідність між тим, що дано суб'єктам навчання об'єктивно в якості предмету вивчення, і тим, як у нього створюється образ наукової картини світу.

Не викликає сумніву, що пізнання суб'єктами навчання є всесильним, дає їм постійні знання, об'єктивну істину. Проте в ході постійного руху за правилами визначеного ланцюжка виникає діалектична суперечність самого процесу утворення знань і їх істинності [3]. 3 огляду на розвиток ІЦК у майбутніх фрахівців комп'ютерних технологій в ході навчання фізики та технічних дисциплін у педагогічному університеті до того часу поки наукові поняття ІЦК відділені від предмету навчання, вони будуть суб'єктивними, бо не очищені від привнесеного суб'єктами чинника. Чим меншою буде така віддаленість, тим реальнішою буде відносна істина. Поступово звільняючись від привнесень суб'єктами знань в процес пізнання предмету, поняття науки постійно втрачають свій абстрактний характер, вони стають істинними і відповідають предмету пізнання. Тобто вирішення суперечностей згідно ланцюжка складає кінцевий підсумок кожного етапу окремого руху пізнання до розкриття чергової істини, як елементу абсолютної істини, до чого намагається дійти особистісне пізнання.

Для аналізу процесу розвитку ІЦК ми використовуємо категорії якості та кількості. У книзі "Наука Логіки" Г.Гегель категорію кількості розглядає за категорією якості. Може скластися думка, що заперечується якісна визначеність речей. Окремі дослідники філософії доводять, що у самій історії природи кількісна визначеність речей виникає після якісної їх визначеності, інакше Г. Гегель не $є$ матеріалістом. Проте мислитель сам дає відповідь: у природі якісна та кількісна визначеність речей така ж, як і нероздільність явища й сутності [1]. 3 точки зору визначеного нами ланцюжка руху пізнання ближче до суб'єктів вивчення є якісна визначеність, яка дається у відчуттях (Л. Фейербах), а кількісна визначеність розкривається не відразу, а у результаті тривалої роботи абстрагуючої думки [14]. Безумовно, кількісні характеристики можливі тоді, коли $є$ пізнання певної якості, 
яку можна описати кількісно. Вказані визначення є результатом аналізу дійсності, що проявляється у предметі пізнання ІЦТ. Аналіз процесу такого пізнання в ході навчання фрізики, техніки, цифрових інформаційних технологій 3 погляду специфіки процесу розвитку приводить до висновку, що в результаті якість виступає первинною, першопочатковим ступенем пізнання предмету, а кількість як більш пізня. На нашу думку, врахування викладеного значною мірою сприяє здоланню суперечності між замовленням освіти на компетентного фахівці 3 комп'ютерних технологій і його готовності до оволодіння ними.

Висновки. Таким чином, у статті розглянуто непросту проблему розвитку методології, яка у дослідженні складає предмет закономірностей вирішення суперечностей між об'єктами та суб'єктами освітнього процесу та способами еволюційного вирішення вказаних суперечностей на прикладі розвитку ІЦК майбутніх фрахівців комп'ютерних технологій в ході навчання фрізики та технічних дисциплін педагогічних університетів.

\section{Використана література:}

1. Гегель Г. Наука логики : в 3-х т. Москва : Мысль, 1970. Т. 1. 501 с.

2. Гончаренко С. У., Кушнір В. А. Методологія як важливий складник наукового дослідження в педагогіці. Неперервна професійна освіта: теорія $і$ практика: наук.-метод. журнал. 2002. Вип. 4(8). C. 15-24. URL: http://lib.iitta.gov.ua/Методологія як важливий складник.pdf (дата звернення: 04.01.2019).

3. Кизима В. В.Діалектика. Філософський енциклопедичний словник / В. І. Шинкарук (голова редкол.) та ін. Київ : Абрис, 2002. 742 с.

4. Концепція розвитку педагогічної освіти: Наказ MOHУ від 16 липн. 2018 р. № 776. URL: https://mon.gov.ua/ua/npa/pro-zatverdzhennya-koncepciyi-rozvitku-pedagogichnoyi-osviti (дата звернення: 31.01.2019).

5. Концепція розвитку цифрової економіки та суспільства України на 2018-2020 роки: Розпорядження Кабінету Міністрів України від 17 січня 2018 p. № 67-p. URL: https://zakon.rada.gov.ua/laws/show/67-2018-\%D1\%80/ed20180117\#n23 (дата звернення: 27.01.2019).

6. Овчарук О. В. Сучасні вимоги до цифрової грамотності в системі шкільної освіти: на основі рамки цифрової компетентності DigComp 2.0. Нова педагогічна думка. 2017. № 4. С. 32-35.

7. Освіта в Україні: базові індикатори. Інформаційно-статистичний бюлетень. Київ : ДНУ “Інституг освітньої аналітики", 2018. 209 с.

8. Основи методології та організації наукових досліджень : навч. посіб. для студентів, курсантів, аспірантів і ад'юнтів / за ред. А. Є. Конверського. Київ : Центр учбової літератури, 2010. 352 с.

9. Про Державний бюджет України на 2018 рік: Закон України від 7 груд. 2017 р. № 2246-VIII. URL: https://zakon.rada.gov.ua/laws/show/2246-19 (дата звернення: 12.06.2019).

10. Про Національну доктрину розвитку освіти: Указ Президента України від 17 квіт. 2002 р. № 347/2002. URL: https://zakon4.rada.gov.ua/laws/show/347/2002 (дата звернення: 01.02.2019).

11. Про Національну стратегію розвитку освіти в Україні на період до 2021 року: Указ Президента України від 25 черв. 2013 р. № 344/2013. URL: https://zakon2.rada.gov.ua/laws/show/344/ 2013/paran10 (дата звернення: 01.02.2019).

12. Про Стратегію сталого розвитку “Україна - 2020”: Указ Президента України 12 січ. 2015 р. № 5/2015. URL: https://zakon.rada.gov.ua/laws/show/5/2015 (дата звернення: 24.02.2019).

13. Садовий М. І., Трифонова О. М. Теорія самоорганізації та синергетики у навчанні студентів педагогічних ВНЗ : посібник. Кропивницький : РВВ КДПУ ім. В. Винниченка, 2017. 184 с.

14. Фейербах Л. Основные положения философии будущего. Сочинения : в 2 томах; пер. с нем. Москва: Наука, 1995. Т. 1. 502 с.

\section{References:}

[1] Hehel' H. (1970). Nauka lohyky: v 3-kh t. Moskva: Mysl'. T. 1. $501 \mathrm{~s}$. 
[2] Honcharenko S. U., Kushnir V. A. (2002). Metodolohiya yak vazhlyvyy skladnyk naukovoho doslidzhennya v pedahohitsi. Neperervna profesiyna osvita: teoriya i praktyka: nauk.-metod. zhurnal. Vyp. 4(8). S. 15-24. URL: http://lib.iitta.gov.ua/Metodolohiya yak vazhlyvyy skladnyk.pdf (data zvernennya: 04.01.2019).

[3] Kyzyma V. V. (2002). Dialektyka. Filosofs'kyy entsyklopedychnyy slovnyk / V. I. Shynkaruk (holova redkol.) ta in. Kyyiv: Abrys. 742 s.

[4] Kontseptsiya rozvytku pedahohichnoyi osvity: Nakaz MONU vid 16 lypn. 2018 r. № 776. URL: https://mon.gov.ua/ua/npa/pro-zatverdzhennya-koncepciyi-rozvitku-pedagogichnoyi-osviti (data zvernennya: 31.01.2019).

[5] Kontseptsiya rozvytku tsyfrovoyi ekonomiky ta suspil'stva Ukrayiny na 2018-2020 roky: Rozporyadzhennya Kabinetu Ministriv Ukrayiny vid 17 sichnya 2018 r. № 67-r. URL: https://zakon.rada.gov.ua/laws/show/67-2018-\%D1\%80/ed20180117\#n23(data zvernennya: 27.01.2019).

[6] Ovcharuk O. V. (2017). Suchasni vymohy do tsyfrovoyi hramotnosti v systemi shkil'noyi osvity: na osnovi ramky tsyfrovoyi kompetentnosti DigComp 2.0. Nova pedahohichna dumka. № 4. S. 32-35.

[7] (2018). Osvita v Ukrayini: bazovi indykatory. Informatsiyno-statystychnyy byuleten'. Kyyiv: DNU "Instytut osvitn'oyi analityky". 209 s.

[8] (2010). Osnovy metodolohiyi ta orhanizatsiyi naukovykh doslidzhen': navch. posib. dlya studentiv, kursantiv, aspirantiv i ad'yuntiv / za red. A. Ye. Konvers'koho. Kyyiv : Tsentr uchbovoyi literatury. $352 \mathrm{~s}$.

[9] Pro Derzhavnyy byudzhet Ukrayiny na 2018 rik: Zakon Ukrayiny vid 7 hrud. 2017 r. № 2246-VIII. URL: https://zakon.rada.gov.ua/laws/show/2246-19 (data zvernennya: 12.06.2019).

[10] Pro Natsional'nu doktrynu rozvytku osvity: Ukaz Prezydenta Ukrayiny vid 17 kvit. 2002 r. № 347/2002. URL: https://zakon4.rada.gov.ua/laws/show/347/2002 (data zvernennya: 01.02.2019).

[11] Pro Natsional'nu stratehiyu rozvytku osvity v Ukrayini na period do 2021 roku: Ukaz Prezydenta Ukrayiny vid 25 cherv. 2013 r. № 344/2013. URL: https://zakon2.rada.gov.ua/laws/show/ 344/2013/paran10 (data zvernennya: 01.02.2019).

[12] Pro Stratehiyu staloho rozvytku "Ukrayina - 2020": Ukaz Prezydenta Ukrayiny 12 sich. 2015 r. № 5/2015. URL: https://zakon.rada.gov.ua/laws/show/5/2015 (data zvernennya: 24.02.2019).

[13] Sadovyy M. I., Tryfonova O. M. (2017). Teoriya samoorhanizatsiyi ta synerhetyky u navchanni studentiv pedahohichnykh VNZ: posibnyk. Kropyvnyts'kyy: RVV KDPU im. V. Vynnychenka, 184 s.

[14] Feyerbakh L. (1995). Osnovnye polozhenyya fylosofyy budushcheho. Sochynenyya : v 2 tomakh; per. s nem. Moskva : Nauka. T. 1. 502 s.

ТРИФоновА Е. М. Методологические аспекты разрешения противоречий в ходе развития информационно-цифровой компетентности будущих специалистов компьютерных технологий.

В статье рассматриваются методологические аспекты решения противоречий в ходе развития информациионно-циифровой компетентности будущзих спецчиалистов компьютерных технологий при обучении физике и техническим дисииплинам в педагогическом учреждении высшего образования на основе Концепции развития циифровой экономики и общества Украины на 2018-2020 года. Эта концуепция, а также парадигма реформирования образования в Украине предусматривают создание современной образовательной среды, где долонна быть преодолена система противоречий между бесконечностью развития предмета познания природь и ограниченностью возможности информационно-иифровой компетентности (ИЦК) субъекта ее познания. Рассматриваются условия создания современной образовательной среды, где должна быть преодолена система противоречий между бесконечностью развития предмета познания природь $и$ ограниченностью возможности информационно-циифровой компетентности субъекта ее познания. Определены методологические предпосылки для обеспечения глобальных изменений цчифровизации образования в направлении его компетентностной модернизации, определень конкретные задачи трансформации образования в цчифровое пространство. Основу методологии составляет процесс развития мылления и формирования мировоззрения субъектов обучения в единой чувственно практической операционной среде самодисциилинь, компетентной работы с информациией, моделями, алгоритмами.

Также в статье рассмотрены аспекты проявления противоречия между бесконечности предмета познания (безусловность) и скінченістю (условность) условий познания, которые решаются в процессе поступательного развития познания в направлении к истине. Решение противоречий согласно цеепочки составляет конечный итог каждого отдельного этапа движения познания к раскрытию очередной истины как элемента абсолютной истинь, к чему 
пытается прийти личностное познание. Решение обозначенных противоречий и составляет предмет исследования, очерченного статьей.

Ключевые слова: циифровое пространство, компьютерные технологии, компетентность, методология, противоречия.

TRYFONOVA O. M. Methodological aspects of distribution of supervisors in the development of information and digital competence of future factors of computer technologies.

The article deals with the methodological aspects of resolving contradictions during the development of information and digital competence of future computer technology specialists in the course of teaching physics and technical disciplines in a pedagogical institution of higher education on the basis of the Concept of the development of the digital economy and society of Ukraine for 2018-2020 years. Conditions of creation of the modern educational environment are considered, where the system of contradictions between the infinity of the development of the subject of knowledge of nature and the limited ability of the information and digital competence of the subject of its knowledge must be overcome. The methodological prerequisites for ensuring global changes in the digitalization of education in the direction of its competent modernization are outlined, and the specific tasks of the transformation of education into digital space are determined. The basis of the methodology is the process of thinking development and the formation of a worldview of subjects of learning in a single sensory practical operational environment of self-discipline, competent work with information, models, algorithms.

The aspects of the contradiction between the infinity of the subject of knowledge (unconditional) and the finality (conditionality) of the conditions of knowledge, which are solved in the process of the progressive development of knowledge in the direction of truth, are considered. At points of bifurcation, such contradictions in cognition are solved and "break through" when the preliminary limit of penetration of cognition in the subject of study is achieved. Violations of the previous historical stage of the limits of the student's knowledge of information and digital technologies and the science of their development are stipulated by the fact that, according to their development trends, capabilities and abilities, they are as infinite and unlimited as the subject of the study itself.

Keywords: digital space, computer technology, competence, methodology, contradictions.

DOI: https://doi.org/10.31392/NZ-npu-143.2019.24

УДК 378.147:[811.111:82-83

Хижун Я. В., Дишлева С. М.

\section{РОЗВИТОК ДІАЛОГІЧНОГО МОВЛЕННЯ У СТУДЕНТІВ ЗВО: АСПЕКТИ ТА ПЕРСПЕКТИВИ ВИКОРИСТАННЯ}

Сьогочасні реалії свідчать про постійне зростання потреб у комунікації та співпраиі між людьми різних національностей та культур, а змінена система освіти та державний освітній стандарт з іноземної мови спонукають до значних змін у самому підході до прочесу викладання, до перегляду та оновлення дидактичних методів навчання іноземних мов у закладах вищої освіти.

У статті розглядаються дидактичні аспекти діалогічного мовлення в контексті комунікативного підходу до вивчення англійської мови та описано досвід використання деяких методичних стратегій, спрямованих на розвиток діалогічного мовлення студентів, узагальнено науково-методичні засоби розвитку діалогічного мовлення на практичних заняттях $з$ англійської мови у студентів ЗВО та наведено деякі стратегії, спрямовані на покращення та вдосконалення розвитку діалогічного мовлення. Щоб досягнути вільного володіння англійською мовою студентами, викладачу необхідно якомога більшу увагу звертати на розвиток 